\title{
ANALISIS USAHA PEMANFAATAN POD KAKAO (Theobroma cacao L.) YANG DIFERMENTASI DENGAN Rhizopus sp, Saccharomyces sp dan Lactobacillus sp TERHADAP BABI JANTAN PERANAKAN LANDRACE
}

\author{
Financial Analysis of Utilization of Pod Cacao (Theobroma cacao L.) Fermented with \\ Rhizopus sp, Saccharomyces sp and Lactobacillus sp for \\ Male Swine Landrace Crossbreed
}

\author{
Idris Kristian Pardosi ${ }^{1}$, Tri Hesti Wahyuni ${ }^{2}$ dan Usman Budi ${ }^{2}$
}

1. Mahasiswa Program Studi Peternakan Fakultas Pertanian Universitas Sumatera Utara

2. Staf Pengajar Program Studi Peternakan Fakultas Pertanian Universitas Sumatera Utara

\begin{abstract}
This research aims to examine the financial analysis of the utilization of cacao pod fermented by Rhizopus sp, Lactobacillus sp and Sacharomyces sp in feed for swine fattening. Financial analysis consisted of profit and loss, IOFC (Income Over Feed Cost) and $R / C$ ratio (Revenue Cost Ratio). The experiments was conducted at Jalan Pintu Air Kwala Bekala Medan from July until September 2012. The research used 20 male swine landrace crossbreed with an average initial body weight for group 1-5:24.76 $\pm 1.31 \mathrm{~kg}, 29.73 \pm$ $1.15 \mathrm{~kg}, 36.30 \pm 4.41 \mathrm{~kg}, 43.38 \pm 2.22 \mathrm{~kg}$, and $49.43 \pm 2.32 \mathrm{~kg}$, respectively. The treatments consisted of $P 0$ (0\%), P1 (10\%), P2 (20\%) and P3 (30\%) cacao pod fermented in diet. This result indicated that treatments gave different results, Total Cost (Rp/head) for treatments for P0, P1, P2 and P3 were 1.545.410,6, 1.489.161,7, 1.451.537,5 and 1.465.170,6, respectively, Total income (Rp/head) were 1.953.840, 1.888.880, 1.850.800 and 1.760.640, respectively, Profit and loss (Rp/head) were 430,829.38; 422,118.34; 421,662.49; and 317,869.4, respectively, while for IOFC (Rp/head) were 901, 600; 875 280; 841 680; and 722. 960, respectively and for $R / C$ ratio were $1.28 ; 1.281 ; 1.29 ;$ and 1,21 , respectively. The conclusion of this research is fermented cacao pod by Rhizopus sp, Saccharomicyes sp and Lactobacillus sp feasible for swine diet.
\end{abstract}

Keyword: Analysis of Financial, Fermented Cacao Pods, Swine

\begin{abstract}
ABSTRAK
Penelitian ini bertujuan untuk mengetahui analisis usaha dari pemanfaatan pod kakao difermentasi dengan Rhizopus sp, Sacharomyces sp dan Lactobacillus sp pada ternak babi peranakan landrace selama penggemukan. Analisis usaha yang dapat dilihat dari Laba-rugi, IOFC (Income Over Feed Cost) dan R/C ratio (Revenue Cost Ratio). Penelitian dilaksanakan di Jalan Pintu Air Kwala Bekala Medan Johor dari bulan Juli sampai bulan September 2012. Penelitian menggunakan 20 ekor ternak babi jantan peranakan Landrace dengan rataan bobot

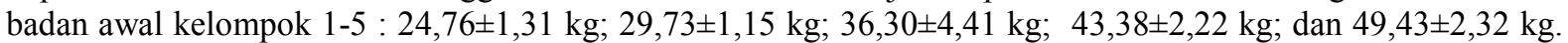
Perlakuan yang diberikan adalah P0 (0\%), P1 (10\%), P2 (20\%) dan P3 (30\%) pod kakao fermentasi dalam ransum. Hasil penelitian menunjukkan bahwa analisis usaha pemanfaatan kulit kakao yang difermentasi dengan Rhizopus sp, Saccharomicyes sp dan Lactobacillus sp memberikan hasil yang berbeda. Hasil penelitian untuk perlakuan P0, P1, P2 dan P3: nilai Biaya produksi (Rp/ekor) berturut-turut 1.545.410,6, 1.489.161,7, 1.451.537,5 dan 1.465.170,6, Hasil produksi (Rp/ekor) berturut-turut 1.953.840, 1.888.880, 1.850 .800 and 1.760.640, Laba-rugi (Rp/ekor) berturut-turut 430.829,38; 422.118,34; 421.662,49 dan 317.869,4, IOFC berturut-turut (Rp/ekor) 901.600; 875.280; 841.680; dan 722.960, R/C ratio berturut-turut 1,28; 1,28; 1,29; dan 1,21 . Kesimpulan dari hasil penelitian ini adalah usaha pemanfaatan pod kakao yang difermentasi dengan Rhizopus sp, Saccharomicyes sp dan Lactobacillus sp layak pada ternak babi.
\end{abstract}

Kata Kunci: Analisis Usaha, Pod Kakao, Fermentasi, Babi. 


\section{PENDAHULUAN}

Analisis usaha ternak babi merupakan kegiatan yang sangat penting bagi suatu usaha ternak yang mempunyai prospek cerah yang dapat dilihat dari analisis usahanya. Berdasarkan data tersebut dapat diukur keuntungan usaha dan tersedianya dana yang riil untuk periode selanjutnya. Melalui usaha ini dapat dicari langkah pemecahan berbagai kendala yang dihadapi. Analisis dapat juga memberikan informasi lengkap tentang modal yang diperlukan, penggunaan modal, besar biaya untuk bibit (bakalan), ransum, kandang, lamanya modal kembali dan tingkat keuntungan uang diperoleh (Suharno dan Nazaruddin, 1994)

Pemerintah berusaha untuk memenuhi dan meningkatkan pendapatan peternak yaitu dengan cara mengembangkan seluruh komoditi ternak yang berpotensi menghasilkan daging sebagai sumber protein diantaranya adalah ternak babi, walaupun tidak semua kelompok masyarakat mengkonsumsi daging babi, namun permintaan terhadap daging babi cukup besar. Sebagaimana diketahui daging babi merupakan ternak penghasil daging yang relatif cepat dan hanya membutuhkan 3 bulan dalam penggemukan sampai masa panen. Hal ini yang menjadi salah satu faktor pendorong peternak dalam mengusahakan peternakan babi.

Keberhasilan peternak babi ditentukan tiga hal yaitu : Breeding, feeding dan manejemen. Breeding adalah merupakan jenis bibit yang digunakan untuk pengemukan ternak, sedangkan feeding yang berkaitan dengan pakan yang digunakan dalam penggemukan, dan pakan merupakan salah satu faktor yang menentukan keberhasilan suatu peternak babi. Dalam menentukan penggunaan pakan hendaknya melihat berbagai faktor diantaranya nilai ekonomi atau harga dari pakan cukup tinggi serta kesinambungan ketersediaan pakan yang tidak sulit memperolehnya. Semakin baik pakan yang digunakan tentu akan berdampak baik terhadap keuntungan, dengan catatan pakan murah tersebut juga berkualitas baik.

Kulit buah kakao (cocoa pod) merupakan limbah agroindustri yang dihasilkan tanaman kakao. Buah kakao terdiri dari 74\% kulit, 2\% plasenta dan 24\% biji. Limbah kulit kakao masih banyak dibuang oleh petani, sehingga dapat sebagai potensi media perkembangan kasus hama penggerek buah kakao (Conomorpha cramerella). Kulit buah kakao yang belum menerima tindakan pengolahan memang kurang baik untuk menjadi bahan pakan ternak babi, hal ini dikarenakan pada kulit buah kakao mengandung zat anti nutrisi berupa lignin dan theobromin, namun dengan menggunakan teknologi sederhana seperti fermentasi, maka kandungan nutrisinya dapat diperbaiki dan anti nutrisinya dapat diturunkan.

Fermentasi adalah proses penguraian unsur-unsur organik kelompok terutama karbohidrat untuk menghasilkan energi melalui reaksi enzim yang dihasilkan oleh 
mikroorganisme. Proses fementasi dapat dikatakan sebagai proses protein enrichment yaitu proses pengkayaan protein bahan dengan menggunakan mikroorganisme tertentu. Berdasarkan uraian di atas maka penulis tertarik untuk mengetahui sejauh mana pengaruh pemberian tepung kulit buah kakao (Theobrema cacao L.,) yang difermentasi dengan Rhizopus sp, Sacharomyces sp, Lactobacillus sp dalam usaha beternak babi.

\section{BAHAN DAN METODE PENELITIAN}

\section{Lokasi dan Waktu Penelitian}

Penelitian ini dilaksanakan di Jalan Pintu Air Kwala Bekala Medan Sumatera Utara. Penelitian ini dilaksanakan selama 2 (dua) bulan, yang dimulai bulan Juli sampai bulan September 2012.

\section{Bahan dan Alat}

\section{Bahan}

Bahan yang digunalan dalam penelitian adalah : 20 ekor ternak babi jantan peranakan landrace umur lima bulan ( 5 bulan) sebagai objek yang diteliti. Bahan pakan terdiri dari tepung pod kakao fermentasi, dedak padi bungkil inti sawit, tepung jagung, kapur kerang, minyak nabati, pig mix, bungkil kedelai, dan tepung ikan sebagai bahan pakan. Air tebu, ragi tape, ragi tempe dan youghurt sebagai fermentor pembuatan inokulen cair. Obatobatan seperti obat cacing (Vermizyn SBK). Air minum.

\footnotetext{
Alat

Alat yang digunakan dalam penelitian ini adalah kandang individual ukuran 1 x $2 \mathrm{~m}$ sebanyak dua puluh unit, beserta perlengkapannya: tempat pakan dan tempat air minum, timbangan duduk untuk menimbang bobot badan hidup berkapasitas $100 \mathrm{Kg}$ dengan kepekaan $100 \mathrm{~g}$ dan timbangan berkapasitas $5 \mathrm{~kg}$ dengan kepekaan $10 \mathrm{~g}$ untuk menimbang pakan alat kebersihan (ember, masker, sepatu boot, sapu lidi, sekop), thermometer ruang sebagai pengukur suhu kandang, alat tulis, kalkulator, alat penerangan, mesin penggiling (grinder) untuk menggiling kulit kakao fermentasi dan terpal plastik untuk alat menjemur pod kakao.
} 


\section{Metode Penelitian}

Adapun metode yang digunakan non eksperimental. Faktor usaha pemanfatan pod kakao pada ternak babi dalam kelayakan usahanya adalah formulasi ransum tiap perlakuan, jumlah kandungan nutrisi tiap perlakuan dan dapat dilihat pada Tabel 1 di bawah.

Tabel 1. Jumlah kandungan nutrisi tiap perlakuan

\begin{tabular}{lrrrr}
\hline Nutrisi & \multicolumn{4}{c}{ Perlakuan } \\
\cline { 2 - 5 } & \multicolumn{1}{c}{ P0 } & P1 & \multicolumn{1}{c}{ P2 } \\
\hline EM (K.kal) & 3283,58 & 3287,58 & 3232,08 & 3206,33 \\
SK & 6,05 & 7,04 & 8,17 & 9,23 \\
LK & 4,77 & 4,17 & 3,64 & 3,07 \\
Ca (\%) & 0,75 & 0,76 & 0,77 & 0,79 \\
P (\%) & 0,95 & 0.78 & 0,62 & 0,46 \\
PK (\%) & 14,56 & 14,35 & 14,27 & 14,24 \\
\hline
\end{tabular}

(Laboratorium Ilmu makanam Ternak. 2012)

Tabel 2. Jumlah bahan pakan dan harga pakan tiap perlakuan $(\mathrm{Rp} / \mathrm{kg})$

\begin{tabular}{|c|c|c|c|c|c|c|c|c|c|}
\hline \multicolumn{10}{|c|}{ Perlakuan } \\
\hline \multirow[b]{2}{*}{ Bahan } & \multirow[b]{2}{*}{ Harga } & \multicolumn{2}{|c|}{ P0 } & \multicolumn{2}{|l|}{ P1 } & \multicolumn{2}{|c|}{ P2 } & \multicolumn{2}{|c|}{ P3 } \\
\hline & & $\begin{array}{c}\text { Jlh } \\
\text { bahan } \\
\text { (kg) }\end{array}$ & $\begin{array}{c}\text { Jlh Total } \\
\text { harga } \\
(\mathrm{Rp} / \mathrm{kg})\end{array}$ & $\begin{array}{c}\text { Jlh bahan } \\
(\mathrm{kg})\end{array}$ & $\begin{array}{c}\text { JlhTotal } \\
\text { harga } \\
(\mathrm{Rp} / \mathrm{kg})\end{array}$ & $\begin{array}{c}\text { Jlh } \\
\text { bhn } \\
(\mathrm{kg})\end{array}$ & $\begin{array}{c}\text { Total } \\
\text { harga } \\
(\mathrm{Rp}) \\
\end{array}$ & $\begin{array}{c}\text { Jlh bhn } \\
(\mathrm{kg})\end{array}$ & $\begin{array}{c}\text { Jlh Total } \\
\text { harga } \\
(\mathrm{Rp} / \mathrm{kg})\end{array}$ \\
\hline T. pod kakao & 1.300 & 0,0 & 0,0 & 10,0 & 130,0 & 20,0 & 260,0 & 30,0 & 390,0 \\
\hline Dedak & 3.000 & 31,5 & 945,0 & 20,5 & 615,0 & 10,5 & 315,0 & 0,0 & 0,0 \\
\hline T. Jagung & 3.000 & 50 & 1500,0 & 50,0 & $1.500,0$ & 50,0 & $1.500,0$ & 50,0 & $1.500,0$ \\
\hline T. Ikan & 6.000 & 7,5 & 450,0 & 7,5 & 450,0 & 7,5 & 450,0 & 7,5 & 450,0 \\
\hline B. Kedelai & 7.000 & 4,5 & 315,0 & 4,5 & 315,0 & 4,5 & 315,0 & 4,5 & 315,0 \\
\hline BIS & 1.600 & 2,0 & 32,0 & 2,0 & 32,0 & 2,0 & 32,0 & 2,0 & 32,0 \\
\hline M. Nabati & 10.000 & 3,5 & 350,0 & 4,5 & 450,0 & 4,5 & 450,0 & 5,0 & 500,0 \\
\hline Pigmix & 18.000 & 0,5 & 90,0 & 0,5 & 90,0 & 0,5 & 90,0 & 0,5 & 90,0 \\
\hline Kapur & 500 & 0,5 & 2,5 & 0,5 & 2,5 & 0,5 & 2,5 & 0,5 & 2,5 \\
\hline Jumlah & & 100 & 3684,5 & 100 & $3.584,5$ & 100 & 3414,5 & 100 & 3279,5 \\
\hline
\end{tabular}

Sumber: Hasil olahan data parameter (2013)

\section{Parameter Penelitian}

\section{Total Biaya Produksi}

Biaya Produksi adalah nilai dari semua korbanan ekonomis yang diperlukan dan yang tidak dapat dihindarkan dapat diperkirakan dan dapat diukur untuk menghasilkan suatu produk. Pengeluaran perusahaan adalah semua uang yang dikeluarkan sebagai biaya produksi (Kadarsan 1995). 


\section{Total Hasil Produksi}

Perusahaan yang beroperasi atau mempunyai kegiatan sesuai dengan di dirikannya perusahaan tersebut akan mengharapkan adanya penerimaan pendapatan dari operasi perusahaan yang dilaksanakan. Bagi perusahaan yang memproduksi barang maka penerimaan pendapatan berasal dari penjualan barang tersebut berasal dari usaha penjualan jasa yang dilakukan perusahaan tersebut (Agus 1990).

\section{Laba/Rugi}

Laporan laba-rugi (income statement) merupakan laporan keuangan yang menggambarkan hasil usaha perusahaan dalam suatu periode tertentu. Dalam laporan laba rugi ini tergambar jumlah pendapatan dan sumber-sumber pendapatan yang diperoleh. Dari jumlah pendapatan dan jumlah biaya ini terdapat selisih yang disebut laba atau rugi. (Kasmir 2008).

\section{Income Over Feed Cost (IOFC)}

Income Over Feed Cost (IOFC) adalah selisih total pendapatan dengan biaya ransum yang digunakan selama usaha penggemukan ternak. IOFC ini merupakan barometer untuk melihat seberapa besar biaya ransum yang merupakan biaya terbesar dalam usaha penggemukan ternak. (Prawirokusumo 1990).

\section{Revenue Cost Ratio (R/C Ratio)}

Analisis $\mathrm{R} / \mathrm{C}$ ratio merupakan alat analisis yang digunakan untuk melihat pendapatan relatif suatu usaha dalam satu tahun terhadap biaya yang dipakai dalam kegiatan tersebut. Suatu usaha dikatakan layak jika nilai $\mathrm{R} / \mathrm{C}$ ratio lebih besar dari $1(\mathrm{R} / \mathrm{C} \leq 1)$. Semakin tinggi nilai $\mathrm{R} / \mathrm{C}$ ratio tingkat keuntungan suatu usaha akan semakin tinggi.

$R / C$ Ratio $>1$ : Efisien; $R / C$ Ratio $=1$ : Impas; dan $R / C$ Ratio $<1$ : Tidak efisien

$\mathrm{R} / \mathrm{C}$ Ratio $=\frac{\text { Total pendapatan }}{\text { Total biaya produksi }}$

(Mahyuddin, 2012) 


\section{HASIL DAN PEMBAHASAN}

\section{Total Biaya Produksi}

Total biaya produksi atau total pengeluaran yaitu biaya-biaya yang dikeluarkan untuk menghasilkan suatu produk, diperoleh dengan cara menghitung: biaya bibit, biaya kandang dan peralatan, biaya pakan, biaya obat - obatan dan biaya tenaga kerja. Biaya produksi tiap perluakuan berbeda dan ini dipengaruhi oleh biaya tidak tetap seperti hal yang disebutkan diatas dapat dilihat pada Tabel 3 di bawah.

Tabel 3. Total rataan biaya produksi tiap perlakuan selama penelitian

\begin{tabular}{lrrrrrr}
\hline \multirow{2}{*}{ Perlakuan } & \multicolumn{6}{c}{ Rataan Biaya (Rp) } \\
\cline { 2 - 7 } & Pakan & Bibit & $\begin{array}{c}\text { Obat- } \\
\text { obatan }\end{array}$ & T.Kerja & $\begin{array}{l}\text { Perlengkapan } \\
\text { \& Kandang }\end{array}$ & $\begin{array}{c}\text { Total } \\
\text { B. Produksi }\end{array}$ \\
\cline { 2 - 7 } & $501.623,22$ & 1.014 .660 & $1.127,4$ & 13.000 & 15.000 & $1.545 .410,6$ \\
\hline P0 & $482.733,86$ & 977.400 & $1.027,8$ & 13.000 & 15.000 & $1.489 .161,7$ \\
\hline P1 & $451.976,31$ & 973.080 & $1.081,2$ & 13.000 & 15.000 & $1.451 .537,5$ \\
\hline P3 & $435.438,80$ & 1.000 .620 & $1.111,8$ & 13.000 & 15.000 & $1.465 .170,6$ \\
\hline
\end{tabular}

Biaya pakan menpengaruhi nilai biaya produksi. Rataan biaya pakan yang paling tinggi pada perlakuan P0 (tanpa pod kakao fermentasi) yaitu sebesar Rp. 501.623,22 sedangkan biaya pakan yang terendah pada perlakuan P3 (30\% pod kakao fermentasi) sebesar Rp. 435.438,80 dan perbedaan harga pakan dipengaruhi oleh banyaknya jumlah tepung pod kakao yang diberikan pada ternak.

Biaya bibit adalah biaya yang dikeluarkan untuk membeli bibit babi sebanyak 20 ekor, dimana harga bobot hidup per kilogramnya Rp. 28.000,00. Biaya bibit tertinggi pada perlakuan P0 yaitu sebesar Rp 1.014.660 dang yang terendah pada perlakuan P2 yaitu sebesar Rp 973.080, P1 sebesar Rp 977.400, P3 sebesar Rp 1.000.620. Perbedaan harga bibit pada tiap perlakuan dipengaruhi oleh bobot badan tiap perlakuan.

Biaya obat-obatan adalah biaya yang dikeluarkan untuk membeli obat untuk ternak babi seperti obat cacing. Pemberian obat cacing pada babi berdasarkan bobot badan, dimana cara pemberiannya 2 gr per $10 \mathrm{~kg}$ bobot badan babi dan harga obat cacing/gr Rp. 150. Biaya obat yang paling tinggi pada perlakuan P0 sebesar Rp. 1.127,4 dan yang paling rendah pada perlakuan P1 sebesar Rp. 1.027,8. Perbedaan biaya obat-obatan pada babi dipengaruhi perbedaan bobot badan babi.

Biaya tenaga kerja adalah biaya yang dikeluarkan untuk memelihara ternak babi selama penelitian. Upah Minimum Regional Provinsi (UMRP) saat penelitian adalah sebesar 
Rp 1.300.000/bulan. Biaya tenaga kerja 1 (satu) bulan adalah $\operatorname{Rp} 6.500$ untuk menangani 1 ekor babi/bulan yang dipelihara secara intensif, sehingga biaya upah tenaga kerja dalam penelitian ini sebesar Rp 260.000 selama penelitian dan biaya upah tenaga kerja tiap perlakuan adalah sama.

Biaya perlengkapan kandang dan sewa kandang adalah biaya yang dikeluarkan untuk membeli perlengkapan kandang dan biaya sewa kandang dan nilai biaya perlengkapan dan sewa kandang tiap perlakuan adalah sama.

Pada Tabel 3 dapat dilihat bahwa total biaya produksi pemeliharaan babi jantan selama penelitian menunjukkan perbedaan besar dimana rataan total biaya produksi tertinggi terdapat pada P0 sebesar Rp 1.545.410,6 dan yang terendah pada P2 sebesar Rp 1.451.537,5.

Perbedaan jumlah pengeluaran ini dikarenakan adanya perbedaan jumlah biaya yang harus dikeluarkan untuk pembelian bibit, pakan, biaya obat-obatan, sewa kandang dan peralatan sedangkan upah tenaga kerja adalah sama. Hal ini seperti dinyatakan oleh Kadarsan (1995) yang menyatakan bahwa biaya adalah nilai dari semua korbanan ekonomis yang diperlukan yang tidak dapat dihindarkan, dan dapat diperkirakan. Ilustrasi perbedaan rataan total biaya produksi (Rp) dari tiap perlakuan dapat dilihat pada Gambar 2 berikut ini :

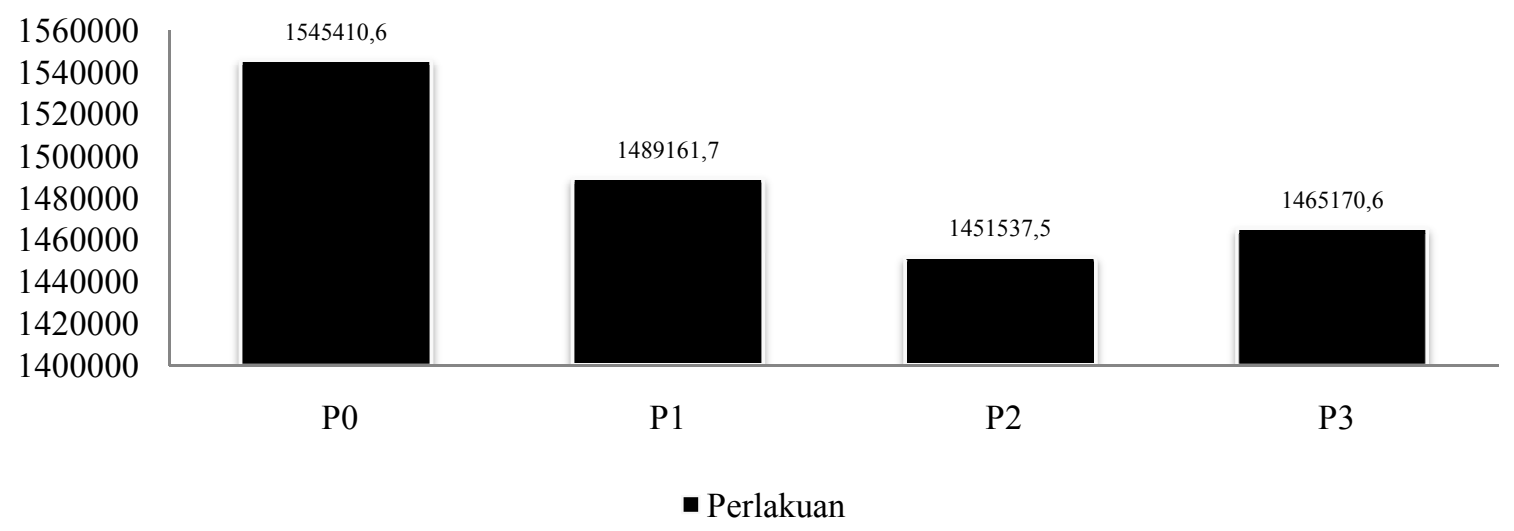

Gambar 2. Grafik rataan biaya produksi selama penelitian.

\section{Total Hasil Produksi}

Total hasil produksi atau total penerimaan yaitu seluruh produk yang dihasilkan dalam kegiatan pemeliharaan babi ini yang diperoleh dengan cara menghitung harga jual babi dan feses. Penjualan feses perlakuan adalah hasil perkalian antara banyaknya feses dengan 
harga jual feses/kg Rp. 100,00 dan hasil penjualan feses tiap perlakuan dengan rataan Rp 22.400/ekor jadi total penjual feses Rp. 448.000.

Penerimaan/hasil produksi pada perlakuan P0 (0\%), P1 (10\%), P2 (20\%) dan P3 (30\%) pod kakao fermentasi dalam ransum menunjukan hasil yang berbeda-beda dengan nilai (Rp/ekor): $1.976 .240,1.911 .280,1.873 .200$ dan 1.783.040, total penerimaan produksi yang tertinggi adalah perlakuan $\mathrm{P} 0(0 \%)$ pod kakao fermentasi dalam ransum. Hal ini dipengarungi oleh perbedaan biaya produksi penelitian.

Total hasil produksi atau total penerimaan yaitu seluruh produk yang dihasilkan dalam kegiatan ekonomi yang diperoleh dengan cara menghitung harga jual babi dan penjualan feses babi. Hasil analisis biaya produksi menjukkan hasil yang berbeda pada tiap perlakuan P0, P1, P2 dan P3 . Hal ini sesuai dengan pernyataan Kadarsan (1990) yang menyatakan bahwa penerimaan adalah hasil penjualan yang diterima produsen. Total hasil produksi atau penerimaan dapat dilihat pada Tabel 4 dibawah.

Tabel 4. Total Hasil Produksi pada Semua Perlakuan Penelitian

\begin{tabular}{lccc}
\hline \multirow{2}{*}{ Perlakuan } & \multicolumn{3}{c}{ Rataan Hasil produksi (Rp) } \\
\cline { 2 - 4 } & Hasil penjualan babi & Feses & Total hasil produksi \\
\hline P0 & 1.953 .840 & 22.400 & 1.976 .240 \\
P1 & 1.888 .880 & 22.400 & 1.911 .280 \\
P2 & 1.850 .800 & 22.400 & 1.873 .200 \\
P3 & 1.760 .640 & 22.400 & 1.783 .040 \\
\hline
\end{tabular}

Perbedaan total hasil produksi dari keempat perlakuan dapat dilihat pada Gambar 3.

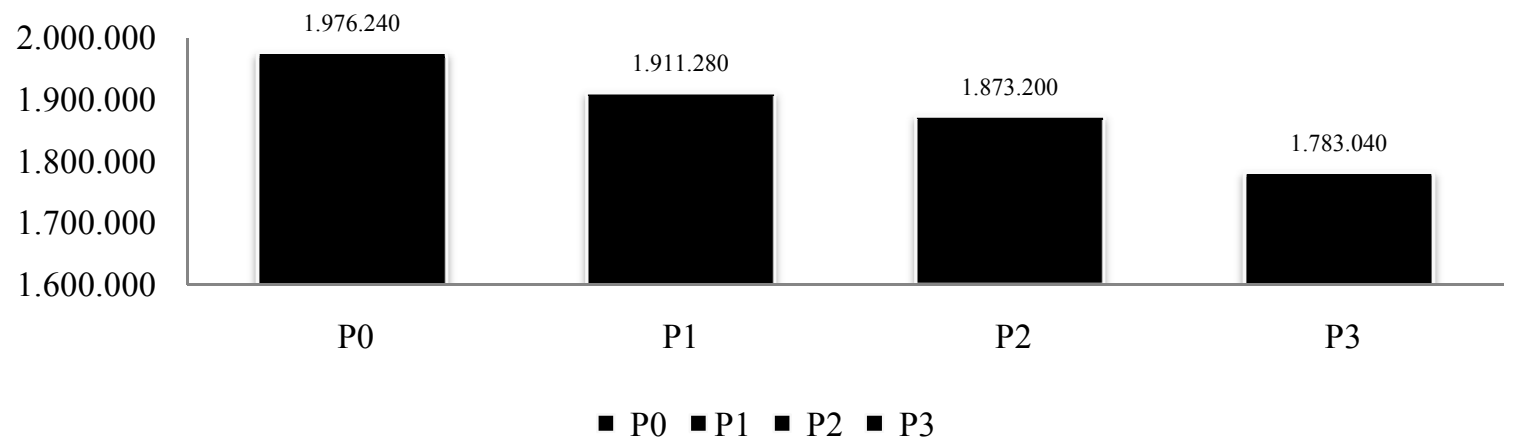

Gambar 3. Grafik rataan hasil produksi penelitian.

\section{Laba/rugi}

Analisis laba rugi dari pemberian kulit buah kakao (Tabel 5) fermentasi memberikan pengaruh yang berbeda-beda pada setiap total level perlakuannya. Masing-masing Perlakuan P0 (0\%), P1 (10\%), P2 (20\%) dan P3 (30\%) memberikan keuntungan (Rp/ekor) dengan 
rataan nilai: 430.829,4, pada 422.118, 421.662 dan 317.119. Dari hasil yang diperoleh dapat dilihat keuntungan tertinggi terdapat pada perlakuan P0 yaitu tanpa pengunaan kulit buah kakao fermentasi dalam pakan, hal ini dikarenakan pertambahan bobot badan babi lebih tinggi dibandingkan dengan perlakuan lain hal ini juga disebabkan terdapat perbedaan harga dan kualitas ransum ditiap level perlakuan.

Total hasil produksi yaitu total penjualan ternak ditambah penjualan feses ternak memiliki nilai yang lebih tinggi dari pada total biaya produksi yaitu biaya pakan, biaya bibit babi, biaya obat-obatan, biaya peralatan dan sewa kandang serta biaya tenaga kerja. Hal ini sesuai dengan Kasmir (2008) yaitu keuntungan adalah yang menyatakan dari jumlah pendapatan dan jumlah biaya ini terdapat selisih yang disebut laba rugi.

Jika pendapatan lebih besar dari jumlah biaya, maka perusahaan dikatakan beruntung, sebaliknya jika jumlah pendapatan lebih kecil dari jumlah biaya produksi, maka perusahaan dikatakan rugi. Untuk memperoleh angka yang pasti mengenai keuntungan atau kerugian yang harus dilakukan adalah pencatatan biaya.

Biaya keluar dan biaya masukan dalam penelitian harus di catat, agar dalam usaha ternak atau pengusaha dapat mengetahui yang perlu di evaluasi terhadap setiap bidang usaha yang dilakukan dan nilai laba-rugi dapat dilihat pada Tabel 5.

Perbedaan rataan Laba/rugi (Rp) dari tiap perlakuan dapat dilihat pada Gambar 4.

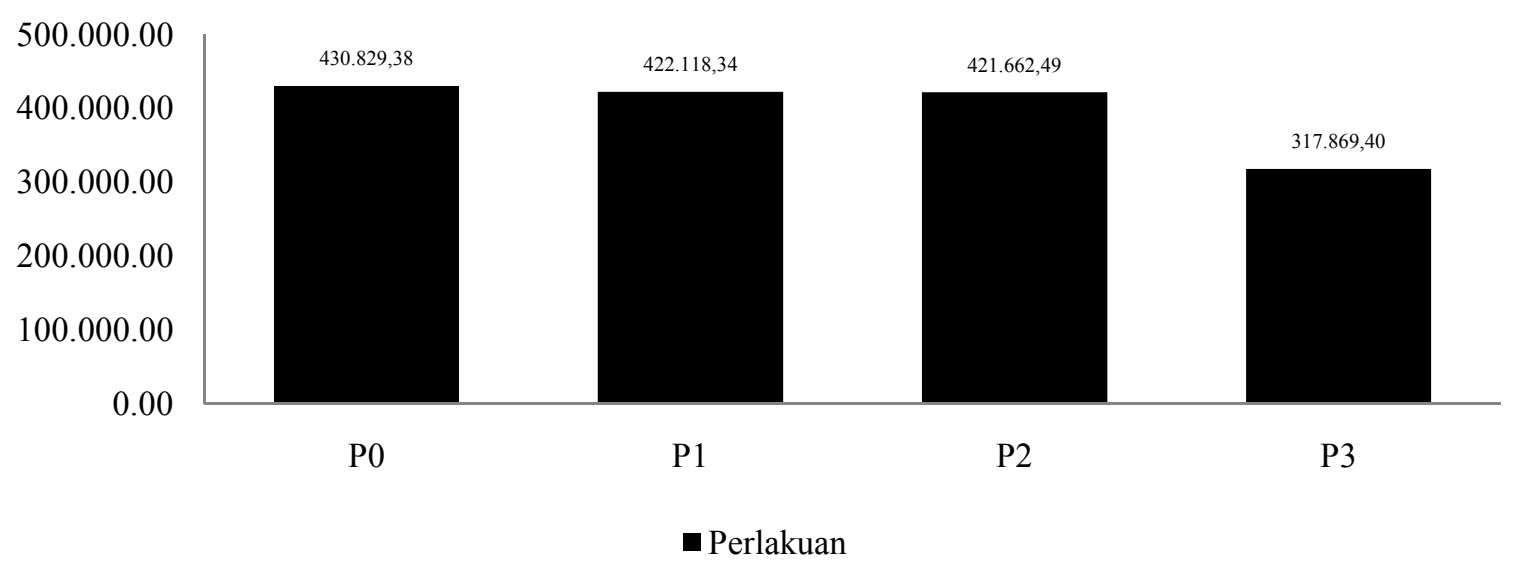

Gambar 4. Grafik rataan Laba/rugi penelitian.

\section{IOFC}

IOFC penelitian tertinggi (Tabel 5) terdapat pada perlakuan P0 yaitu dengan nilai rataan $\mathrm{Rp}$ 901.600/ekor, hal ini dikarenakan bobot badan babi yang tinggi dikalikan harga jual perkilogram babi sehingga pendapatan penjualan babi lebih tinggi dari pada total biaya 
yang dikeluarkan untuk konsumsi babi tersebut, dan juga dipengaruhi oleh tingkat konsumsi babi, dan diikuti pertambahan bobot badan babi.

IOFC terendah terdapat pada perlakuan P3 dengan nilai rataan $\quad$ Rp 722.960/ekor, hal ini dikarenakan bobot badan akhir babi rendah dari perlakuan yang lain sehingga menyebabkan harga jual babi lebih rendah dengan perlakuan yang lain. Hal inilah yang menyebabkan IOFC pada perlakuan P3 paling rendah dibandingkan dengan perlakuan lain. Hal ini sesuai dengan pernyataan Prawirokusumo (1990) bahwa pendapatan usaha peternakan itu dibandingkan dengan biaya pakan.

IOFC ini merupakan barometer untuk melihat seberapa besar selisih total pendapatan dengan biaya pakan yang digunakan selama penggemukan ternak. IOFC diperoleh dengan menghitung selisih pendapatan usaha peternakan dikurangi biaya pakan. Pendapatan merupakan perkalian antara produksi peternakan atau pertambahan bobot badan akibat perlakuan dengan harga jual pada ternak, dan IOFC tiap perlakuan dapat dilihat pada Tabel 5.

Perbedaan rataan Laba/rugi (Rp) dari tiap perlakuan dapat dilihat pada Gambar 5.

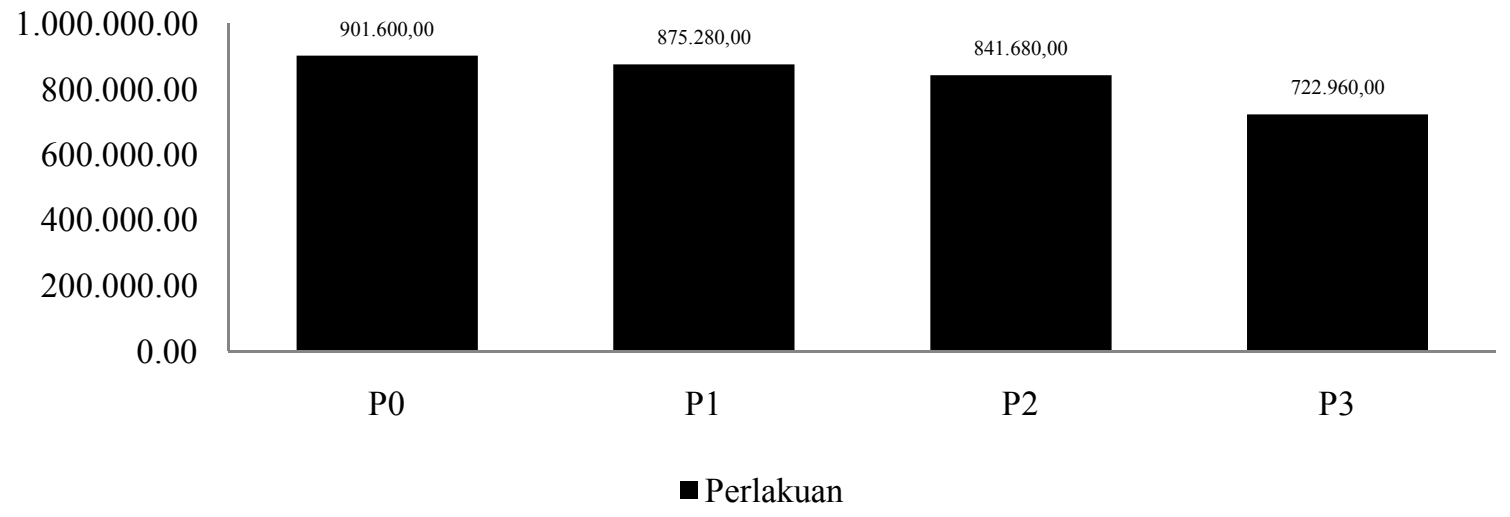

Gambar 5. Grafik rataan IOFC penelitian.

\section{$\mathrm{R} / \mathrm{C}$ ratio}

$\mathrm{R} / \mathrm{C}$ ratio (Tabel 5) penelitian merupakan perbandingan antara total penerimaan dengan total biaya. Penelitian $\mathrm{R} / \mathrm{C}$ ratio, nilai tertingginya diperoleh pada perlakuan $\mathrm{P} 2$ sebesar 1,29 dan nilai terendah diperoleh pada P3 sebesar 1,21 dan hal ini dikarenakan perbedaan hasil produksi dengan biaya produksi.

$\mathrm{R} / \mathrm{C}$ ratio penelitian ini menunjukkan setiap perlakuan memberikan nilai $>1$, yang artinya setiap perlakuan layak untuk usaha ternak babi. Suatu usaha dikatakan memberikan manfaat bila nilai $\mathrm{R} / \mathrm{C}$ Ratio $>1$. Makin besar $\mathrm{R} / \mathrm{C}$ ratio makan usaha tersebut semakin efisien hal ini sesuai dengan pernyataan Mahyuddin (2012), yang menyatakan bahwa Analisis 
$\mathrm{R} / \mathrm{C}$ ratio merupan alat analisis yang digunakan untuk melihat pendapatan relatif suatu usaha dalam satu periode terhadap biaya yang dipakai dalam kegiatan tersebut. Suatu usaha dikatakan layak jika nilai $\mathrm{R} / \mathrm{C}$ ratio lebih besar dari $1(\mathrm{R} / \mathrm{C} \leq 1)$.

Perbedaan rataan Laba/rugi (Rp) dari tiap perlakuan dapat dilihat pada Gambar 6.

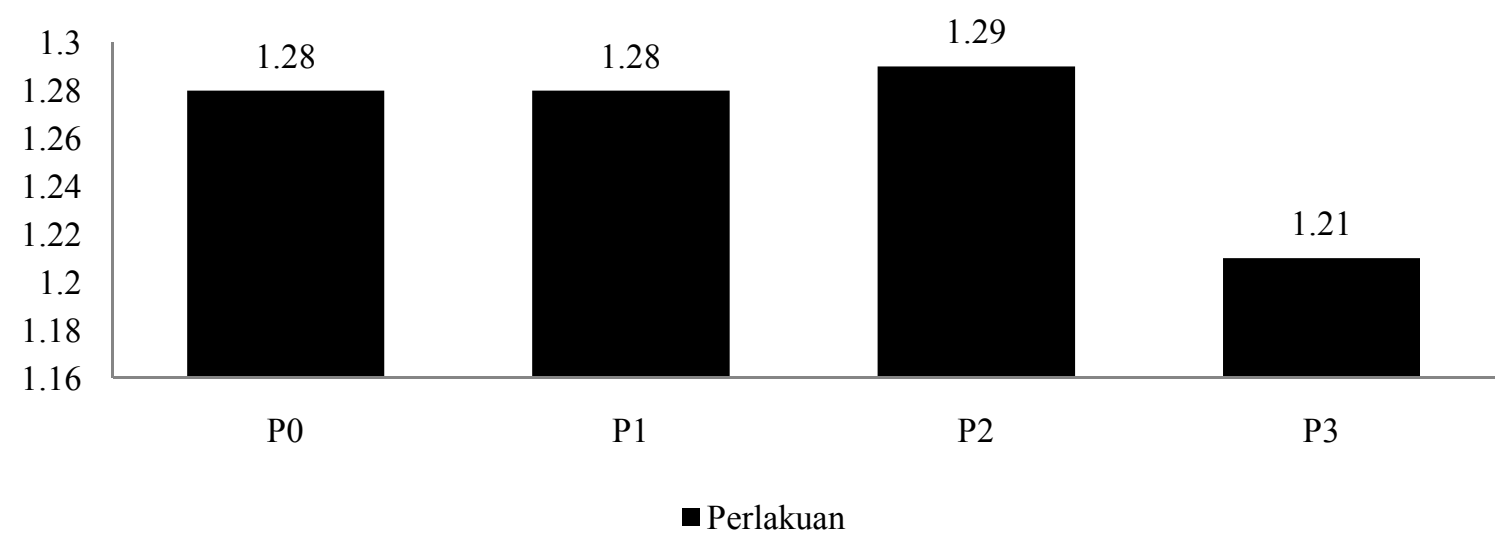

Gambar 6. Grafik rataan R/C ratio penelitian.

Analisis $\mathrm{R} / \mathrm{C}$ ratio dalam penelitian ini merupakan alat analisis yang digunakan untuk melihat pendapatan relatif suatu usaha dalam satu periode terhadap biaya yang dipakai dalam penelitian ini, dan nilai $\mathrm{R} / \mathrm{C}$ ratio dapat dilihat pada Tabel 5.

Tabel 5. Hasil analisis kelayakan usaha.

\begin{tabular}{lccc}
\hline Perlakuan & Laba/rugi & IOFC & R/C ratio \\
\hline P0 & $430.829,38$ & 901.600 & 1,28 \\
P1 & $422.118,34$ & 875.280 & 1,28 \\
P2 & $421.662,49$ & 841.680 & 1,29 \\
P3 & $317.869,40$ & 722.960 & 1,21 \\
\hline
\end{tabular}

\section{KESIMPULAN}

Kesimpulan dari hasil penelitian ini adalah usaha pemanfaatan pod kakao yang difermentasi dengan Rhizopus sp, Saccharomicyes sp dan Lactobacillus sp layak pada ternak babi.

\section{DAFTAR PUSTAKA}

Agus 1990 Analisis Peluang Pokok. UGM Press. Yogyakarta.

Compost Centre. 2009. Guidelines Training On Compost : A Takakura Method. Sumatera Utara University Campus Medan.

Kadarsan H. 1995. Keuangan Pertanian dan Pembiayaan Perusahaan Agribisnis Cetakan Kedua. Gramedia Jakarta. 
Kasmir 2008. Analisis Laporan Keungan. Raja Grafindo Persada. Jakarta.

Laboratorium Ilmu makanam Ternak. 2012. USU. Medan.

Mahyuddin K. 2012. Panduan Lengkap Agribisnis, Penebar Swadaya. Jakarta

Prawirokusumo S. 1990. Ilmu Gizi Komparatif. BPFE Yogyakarta. 